as an ornamental stone. There is a somewhat exceptional niligling of sound geology and mining applications in this compact report. The Survey shows a keen interest in palæontology in its Records, vol. viii., part iv. (I909, price $\%$. 6d.). Mr. R. Etheridge, among other contributions by him, describes a large tubular organism from Gotlandian strata, allied to the Carboniferous Mitchelcieania. Dr. A. S. Woodward adds to our knowledge of the labyrinthodont Bothriceps. Mr. G. W. Card continues his painstaking determinations of the minerals of the State, and the analyst, Mr. J. Mingaye, supplies details of importance to all chemists as to the modes of separation of thoria from monazite (p. 276).

Mr. W. E. Cameron has written for the Queensland Geological Survey a second report on the Etheridge Golufield (Brisbane, Ioog), where the ores occur in reefs in granite, or associated, like those of the Drake Field in New South Wales, with basic dykes, which here penetrate schists. The Survey has also issued a third edition of a very useful geological and mining nap of Queensland, on the scale of $I$ inch to forty miles.

In Bulletin No. 6 of the New Zealand Geological Survey (Igo8, price 2s. 6d.) Mr. P. G. Morgan describes the southern part of North Westland, on the western coast of the South Island. The author feels strongly that high ground existed in the oceanic area to the west down to the commencement of Pliocene times (pp. 34 and 37 ), and

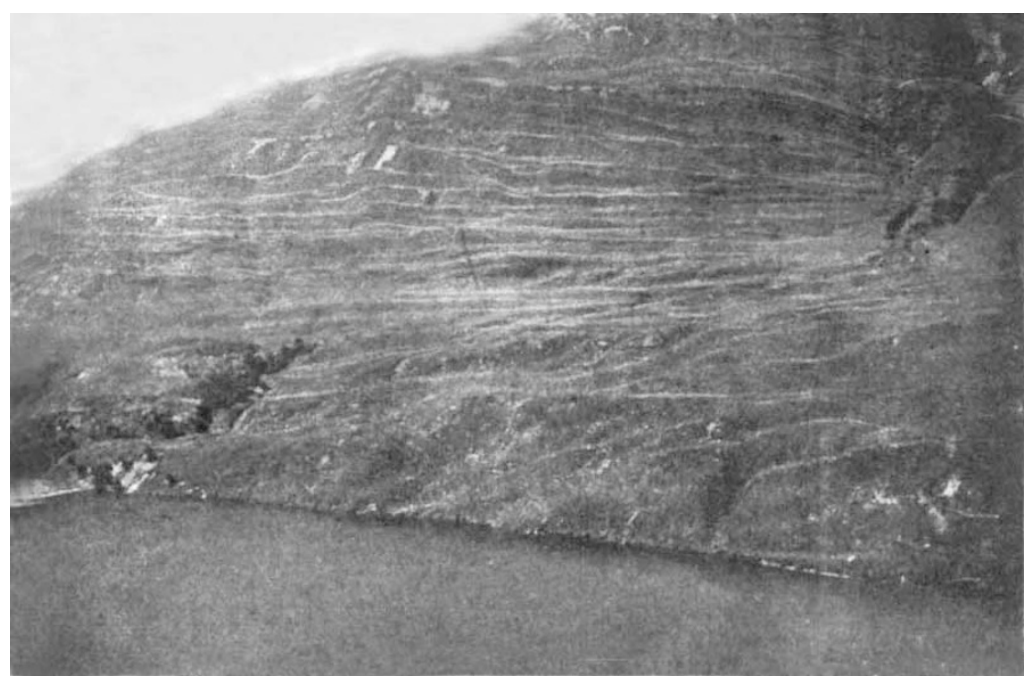

Fig. 3.-Ice-carved terraceš on slope of Ben More, Western Otago.

hemisphere, are here illustrated from $45^{\circ}$ south latitude. Especially remarkable, however, are the terraces carved out on Ben More above Lake Luna, in a quartzose micaschist (p. 3I), which Prof. Park believes to be unique features of ice-erosion (Fig. 3). The author contributes a short essay on ice-flow and the excavating powers of glaciers. References to the structure of glacier-ice and to experiments on its plasticity would have rendered this more complete, but enough is said to excite interest. The bulletin concludes with an account of local gold-mines, and the maps cover the important areas in which. alluvium has been worked, or in which the quartz-reefs seem of promise. As usual, for beauty of illustration and the excellent production of the accompanying maps, these New Zealand bulletins remain unsurpassed.

G. A. J. C.

\title{
THE LINNEAN SOCIETY'S DISCUSSION ON THE ORIGIN OF VERTEBRATES.
}

DURING the past fifty years one of the chief tasks to which zoologists have applied themselves has been the reconstruction of the phylogeny of the animal kingdom in accordance with the principles of evolution laid down by Charles Darwin. This task is still far from being completed, although no one can doubt that very substantial progress has been made. The evidence is still very imperfect, and every increase of knowledge makes more clear the need for extreme caution in drawing conclusions. When we think of the familiar comparison of the animal kingdom to a luxuriantly branching tree of which only a few of the topmost twigs are known to us in the living condition, while at the same time we are only able to recover from the past the most fragnentary records of the millions of extinct forms, we are able to realise why it, is that most zoologists at present refuse to commit themselves to any particular theory of the origin of vertebrates. Of course, numerous theories have been put for. ward from time to time, but none has met with anything like general acceptance, and there appears to be a widespread feeling that in the present state of our knowledge any such theory is somewhat premature. The discussion of the subject, however, cannot fail to be of use in stimulating thought, and the debate which has occupied the last two meetings of the Linnean Society has naturally aroused considerable interest.

that this land disappeared only when the present Alps of New Zealand rose towards their maximum height. A relic is believed to remain in the Carboniferous Greenland stites (p. 96), which is folded almost at right angles to the trend of the Southern Alps. The conglomerates of the Oligocene or Miocene Koiterangi series (p. 102) are at first glacial and then fluviatile, and their pebbles may liave descended from the old western highlands. The modern glacial features of the interior furnish material for several striking photographs (Fig. 2).

Prof. James Park, in Bulletin No. 7 (I9o9, price 2s. 6d.), has an equally grand field in the Queenstown subdivision of western Otago. Queenstown lies on the winding Lake Wakatipu, which is fifty miles in length, and close against serrated Alpine ranges. The main theme of this splendidly illustrated monograph is the evidence for widespread Pleistocene glaciation in the South Island. All the sions of confluent glaciers, developing into an ice-sheet, are here brought together in an argument that appears complete. The decline of the ice seems to have been as rapid as in Eutope, giving rise to " unparalleled fluviatile activity" (p. 41). The late Pliocene elevation of the country is held to have had considerable influence on the refrigeration, and the Pleistocene subsidence was accompanied by recession of the ice. Striated surfaces, boulder-clays, drumlins, eskers, and all the features familiar in our NO. $2 \mathrm{IO} 2$, VOL. 82]
Dr. Gaskell, as opener, expounded, in his usual brilliant style, his own particular theory of the origin of vertebrates from an arthropod ancestor. This theory has already been before the scientific public for many years, but has met with little favour amongst professional zoologists, most of whom find it impossible to believe that a highly specialised Limulus-like arthropod could have given rise to such a very different type of organisation as the vertebrate. Dr. Gaskell, as is well known, bases his argument mainly upon his study of the Ammocoetes larva of the lamprey, between which and the king-crab he endeavours to draw a very close comparison.

The keynote of this comparison lies in the central nervous system. The ventricles of the brain, with their lining epithelium, are supposed to represent the arthropod stomach, and the central canal of the spinal cord the intestine. The infundibulum is the ancestral osophagus, and the neurenteric canal the ancient vent. Around this tubular foundation the various ganglia of the arthropod nervous system have become arranged to form the nervous tissue of the vertebrate brain and spinal cord. The original functions of the ancestral alimentary canal have disappeared, and it has been finally replaced by an entirely new structure developed from a respiratory chamber in some palæostracan ancestor. 'This theory, of course, lands us in a serious difficulty from the embryological point of 
view, for if we accept it we must admit that the germlayers in arthropods and vertebrates are not homologousthat the epiblast of the one becomes the hypoblast of the other, and vice versa. Dr. Gaskell does not find this difficulty by any means insuperable, and, as part of his argument, runs a tilt against the germ-layer theory as at present accepted. In this he was largely supported by the subsequent observations of Dr. Gadow and Prof. Stanley Gardiner.

The debate naturally centred around Dr. Gaskell's theory, which was discussed from the standpoints of embryology, comparative anatomy, palæontology, physiology, and even psychology, the subsequent speakers being Prof. MacBride, Prof. Starling, Mr. Goodrich, Dr. Gadow, Dr. Smith Woodward, Prof. Dendy, Sir Ray Lankester, Dr. Chalmers Nitchell, Prof. Stanley Gardiner, the Rev. T. R. R. Stebbing, and the president (Dr. D. H. Scott). Dr. Gaskell replied at length at the end of the second evening.

It is impossible in this article to give more than a very general account of the course of the discussion, and this is the less necessary as the Linnean Society has announced its intention of publishing it in full, while Dr. Gaskell's views have recently been given to the world in book form.

For reasons which have already been indicated, no definite theory was put forward as a rival to that of Dr. Gaskell, though probably no competent zoologist would have much difficulty in formulating such a theory. Amphioxus, however, looned larse, especially in the remarks of Mr. Goodrich. Dr. Gadow, whose remarks, on the whole, tended strongly to support Dr. Gaskell, expressed the opinion that the attempts which have been made to bring Amphioxus into line have not been successful, but it was pointed out that this animal, though in some respects undoubtedly modified-according to Sir Ray Lankester, even degenerate-nevertheless more nearly resembles a primitive vertebrate than any other animal living at the present day. Probably no zoologist now claims it as being in the direct line of descent of the higher vertebrates from their invertebrate ancestors, but it has gone off on its own little side-track for only i short distance from the starting point. In many respects it retains primitive vertebrate characters, such as the notcchord, the numerous gill slits, and the comparativeis undifferentiated central nervous system (which may, howcver, be partly explained as due to degeneration). It shows hardiy any sign of cephalisation, and no trace of the paired sensc organs which form so dominant a feature of the organisation in higher vertebrates. It represents an altogether lower grade of organisation than the lamprey or even the Ammocoetes larva, yet, as Dr. Goodrich clearly showed, there is no difficulty in deriving the lamprey from an Amphioxus-like ancestor by a normal process of evolution in which cephalisation has played the leading part. If, however, we accept an Amphioxus-like ancestor as tho starting point of the vertebrate phylum, we must put the arthropod theory out of court at once, for many of the structures upon which Dr. Gaskell lays much stress as evidence in support of his theory, such as the lateral and pineal eyes, have not yet appeared at the commencement of the vertebrate series, and must have been evolved within the limits of the phylum.

As to what preceded the Amphioxus-like ancestor of vertebrates, zoologists, as already observed, refuse to commit themselves to an opinion. They await more evidence. In the meantime, it is pointed out that the possession of nephridia with solenocytes, identical with those of certain chatopod worms, suggests annelidan affinities, and that the worm-like Balanoglossus, with its Amphioxus-like gill slits but very dubious notochord, must also be taken into account, while the evidence of embryology points to some far remote relationship bctween Amphioxus, Balanoglossus, and the echinoderms.

The chief difficulty in the way of comparing the vertebrate with the annelid lies, of course, in the reversal of the surfaces which such comparison implies. In the annelid the principal part of the central nervous system lies ventrally beneath the gut, in the vertebrate it lies dorsally above the gut. Dr. Gaskell maintains that the old way of getting over this difficulty by turning the animal upside down and making the dorsal surface of the vertebrate represent the ventral surface of the invertebrate ancestor is now universally discredited. Yet we find Prof: Sedgwick saying in his "Text-book of Zoology," so recently as 1905, that it is quite clear that the dorsal surface of the vertebrate corresponds to the ventral surface of other colomates, a view which is strongly supported by the history of the ascidian tadpole, in which the mouth is dorsally situated, instead of ventrally, as in higher chordates.

A considerable amount of detailed criticism of Dr. Gaskell's theory was, of course, brought forward during the discussion. Prof. MacBride pointed out that the skin of the primitive vertebrate must have been ciliated, while in the arthropod the entire organisation is dominated by the production of a thick, chitinous cuticle. He also spoke $i_{i}$ defence of the germ-layer theory, and criticised Dr. Gaskell's explanation of the hollow gastrula stage of the irthropod Lucifer, the existence of which seems clearly to indicate that the two primary layers of arthropods are dentical with those of vertebrates.

An attempt was also made by the present writer to show that Dr. Gaskell's interpretation of the lateral and pineal eyes of vertebrates as the homologues of the lateral and median eyes of arthropods would not bear the test of critical examination. 'The same speaker endeavoured to explain the hollow tubular character of the vertebrate central nervous system as a comparatively recent adaptation to the requirements of the vertebrate organisation, in which the necessary increase of surface is brought about by the familiar process of folding. Dr. Chalmers Mitchell directed attention to the mode of origin of the nervous system in various invertebrate groups, and scored a point against Dr. Gaskell by his reference to the recent conclusions of Prof. C. Judson Herrick with regard to the arthropodan nervous system.

Prof. Starling maintained that, as regards the principles which must guide any research into the phylogeny of our race, a physiologist has as good a right to be heard as a comparative anatomist, and he thinks that "it is as difficult to conceive that the vertebrate was evolved from a primitive worm-like organism which shot up past the more highly developed Arthropoda as it is to believe that mankind is destined to be replaced by some beast that is now being evolved from lower groups in the depths of the sea," The observations of Dr. Smith Woodward, on the other hand, which dealt with the subject from the palæontological point of view, seemed to indicate that the process of evolution takes place very much in the way which Prof. Starling finds it so difficult to imagine. Moreover, the claims of the ancient ostracoderms to arthropodan affinities upon which Dr. Gaskell lays so much stress, seem to be extremely dubious; they were probably highly specialised forms, perhaps related in some respecis: to the lampreys.

Though unable th accept his views on the subject before the meeting, Sir Rav Lankester voiced what must have been a very general feeling amongst those present in expressing his appreciation of Dr. Gaskell's observations.

Arthur Dendy.

\section{UNIVERSITY AND EDUCATIONAL} INTELLIGENCE.

CAMBRIDGE.-The Vice-Chancellor gives notice that the Sadlerian professorship of pure mathematics is vacant. The election to the professorship will take place on Monday, February 28. Candidates are requested to send their names to the Vice-Chancellor on or before Saturday, February in.

The office of superintendent of the museum of zoology is vacant by the resignation of Prof. Punnett. The stipend at present attached to the office is $200 l$. per annum. Applications should be sent to the chairman of the special board for biology and geology (Prof. Langley, The Museums, Cambridge) on or before March 7 .

Mr. J. C. F. Fryer has been elected to the Balfour studentship from March 25 .

A grant of $200 l$. has been made from the Balfour fund to Mr. C. F. Cooper, for an investigation into the Tertiary vertebrate fauna of India, and a grant of $40 l$. to $\mathrm{Mr}$. K. R. Lewin, in furtherance of his work in protozoology to be carried on abroad.

The following grants were made in the year 5909 frem 